\title{
Gross Domestic Product FP-Causes Life Expectancy at Birth
}

\author{
Gordon G. Bechtel \\ Warrington College of Business, University of Florida, Gainesville, USA \\ Email: bechtel@ufl.edu
}

How to cite this paper: Bechtel, G. G. (2021). Gross Domestic Product FP-Causes Life Expectancy at Birth. Open Journal of Social Sciences, 9, 325-332.

https://doi.org/10.4236/jss.2021.96024

Received: April 28, 2021

Accepted: June 22, 2021

Published: June 25, 2021

Copyright (c) 2021 by author(s) and Scientific Research Publishing Inc. This work is licensed under the Creative Commons Attribution International License (CC BY 4.0)

http://creativecommons.org/licenses/by/4.0/

\begin{abstract}
This article demonstrates that GDP FP-causes life expectancy at birth. The confirming fractional polynomial regression in Section 3.2 is run over the pre-pandemic period 1991-2018. During the subsequent pandemic, the American Center for Disease Control reported that life expectancy at birth in the USA dropped one year during the first six months of 2020, the largest drop since World War II. The drops in African and Hispanic life expectancy at birth during this period were 2.7 and 1.9 years (Aljazeera; Democracy Now, February 18, 2021). The USA is the worst COVID-19-effected population. It is now imperative to verify that life expectancy at birth is well predicted from GDP in all nations over 1991-2018. This pre-pandemic control for each nation will accurately calibrate its subsequent yearly survival drops due to COVID-19. This is especially important in light of the trade war between the United States and China, which has increased the need for the precise measurement of the human effects of this war.
\end{abstract}

\section{Keywords}

A Theory of Imperatives, COVID-19, Fractional-Polynomial Transformation of GDP, Life Expectancy at Birth, Pandemic Threats to Lives and Economies, $\mathrm{R}^{2}$ Invariance with Respect to GDP and Survival Calibration

\section{Introduction}

The United Nation's Secretary General Antonio Guterres has recently advocated reforms of the World Bank, the International Monetary Fund, and the UN Security Council (Aljazeera, accessed on 19 July, 2020). Guterres stresses that events have overtaken us (www.nelsonmandela.org/content/page/annual-lecture-2020):

- The corona virus has brought the world to the breaking point and exposed deep demographic inequalities. 
- A new UN governance would give each nation an equal vote and no veto.

- A new social contract would create equal opportunity at all institutional levels.

- An inclusive and balanced multilateral trading system would provide sustenance and sustainability.

Guterres reiterated these issues at the United Nations $75^{\text {th }}$ anniversary on September 21, 2020. Pursuing "the future we want, the United Nations we need", the UN passed a Declaration of International Collaboration advocating an egalitarian reformation of the UN as well as the entire global establishment. Ten weeks later Guterres implicitly admonished some of the G20 nations for their rejection and ignorance of the World Health Organization's information and guidance in addressing poor nation's poverty, hunger, and survival in the COVID-19 pandemic: "When countries go in their own direction, the virus goes in every direction" (Aljazeera, December 3, 2020). Pivoting to climate change, Guterres then requested governments to declare climate emergencies in their own countries: "This is a moment of truth and it is also a moment of hope" (Aljazeera, December 12, 2020). Echoing Guterres at the World Economic Forum in Davos, Switzerland on 1/25/2021, Xi Jinping said: "We must build an open world economy, firmly safeguard the multilateral trade system, and refrain from making discriminating and exclusive standards, rules, and systems, as well as high walls that separate trade, investment, and technology" (https://www.euractiv.com).

These recent moments of truth and hope suggest life expectancy as perhaps the world's most crucial imperative. This then points to GDP as the gateway to a population's comfort, security, and well-being.

Sections 2 and 3 give the World Bank's description of life expectancy at birth in years and GDP in trillions of current US\$. Section 4 shows that world GDP drives world life expectancy at birth and Section 5 discusses these two indicators in the new social data science. This section also emphasizes that these two indicators are measured on ratio scales, which exceed interval scales in the hierarchy of scientific measurement (Stevens, 1946; Torgerson, 1958; Suppes \& Zinnes, 1963). Section 6 summarizes the major discovery here; namely, world GDP in trillions of current US\$ FP-causes world life expectancy in years. This work relies on two data definitions and one fractional-polynomial regression. The efficacy of these definitions and their regression will be tested in the coming weeks when the G7 and G20 nations debate the economic tradeoffs between rich and poor countries.

\section{Life Expectancy at Birth (Years)}

The following details for the variable life expectancy at birth are given by the World Bank (http://beta.data.worldbank.org/):

Life expectancy at birth indicates the number of years a newborn infant would live if prevailing patterns of mortality at the time of its birth were to stay the same throughout its life.

Source: 1) United Nations Population Division. World Population Prospects: 
2019 Revision derived from male and female life expectancy at birth from sources such as: 2) Census reports and other statistical publications from national statistical offices, 3) Eurostat: Demographic Statistics, 4) United Nations Statistical Division. Population and Vital Statistics Report (various years), 5) U.S. Census Bureau: International Database, and 6) Secretariat of the Pacific Community: Statistics and Demography Programme.

Development Relevance. Mortality rates for different age groups (infants, children, and adults) and overall mortality indicators (life expectancy at birth or survival to a given age) are important indicators of health status in a country. Because data on the incidence and prevalence of diseases are frequently unavailable, mortality rates are often used to identify vulnerable populations. And they are among the indicators most frequently used to compare socioeconomic development across countries.

\section{GDP (Trillions of Current US\$)}

History of GDP. In the great depression Simon Kuznetz formulated American national accounts in terms of dollars, which evaluated different commodities in a common unit. He added up various national income sources and reported his result to the United States Senate in January, 1934 (Masood, 2016, Prologue, Chapters 2 and 3). "In 1940, six years after Simon Kuznetz had presented his national income estimates to the Senate, Keynes had written down in a table the basis for what today is the formula for GDP” (Masood, 2016: p. 26). This formula adds up three macro indicators, household expenditure, domestic savings, and government expenditure, which constitute Keynesian GDP.

Importance of GDP. In 1999, mindful of Simon Kuznets original accounting of distinct goods like cars and cereal boxes by their dollar values, the United States Commerce Department proclaimed the GDP formula as the U.S. government's greatest invention of the 20th century (Masood, 2016, Introduction). The calibration of GDP's three indicators in current US dollars for all nations signals a continuing American control of the global economy. In the plethora of global indexes, GDP looms as the composite most fundamental to the global economy. GDP is so basic, longstanding, and prestigious that market traders, analysts, and policy planners track it daily on worldwide television and internet. The new empirical economics is dominated by GDP's "Making the Modern World" (Masood, 2016, Preface), it's fostering human development, and its availability in most national accounts.

Indicators of GDP. Here we view GDP's components, household expenditure, domestic savings, and government expenditure, as separate time-varying indicators (http://beta.data.worldbank.org):

Household final consumption expenditure (current US\$): "Household final consumption expenditure (formerly private consumption) is the market value of all goods and services, including durable products (such as cars, washing machines, and home computers), purchased by households. It excludes purchases of dwellings but includes imputed rent for owner-occupied dwellings. It 
also includes payments and fees to governments to obtain permits and licenses. Here, household consumption expenditure includes the expenditures of nonprofit institutions serving households, even when reported separately by the country. Data are in current U.S. dollars."

Gross domestic savings (current US\$): "Gross domestic savings are calculated as GDP less final consumption expenditure (total consumption). Data are in current U.S. dollars."

The World Bank's update of John Maynard Keynes final indicator, added during World War II (Keynes, 1940), is:

General government final consumption expenditure (current US\$): "General government final consumption expenditure (formerly general government consumption) includes all current government expenditures for purchases of goods and services (including compensation of employees). It also includes most expenditures on national defense and security, but excludes government military expenditures that are part of government capital formation. Data are in current U.S. dollars."

This dollar denomination of variables counted in different units (automobiles, cereal boxes, etc.) allows the ratio scaling of GDP up to a multiplier calibrating GDP in single, thousands, millions, billions, or trillions of current US dollars. This ratio scaling also allows daily exchange-rates to multiply one nation's currency into another's (e.g. dollars into yuan).

\section{World GDP $(G)$ as an FP-Cause of World Life Expectancy at Birth $(E)$}

This paper shows that $G F P$-causes $E$ in year $t=1991 \ldots 2018$, where $F P$ denotes fractional polynomial (cf. Royston \& Altman, 1994; Granger, 2001).

Definition 1. Vectors $G$ and $E$ replicate constants $G_{t}$ and $E_{t} N_{t}$ times and contain $\Sigma_{t} N_{t}$ values, where $N_{t}$ is population size in year $t=1991 \ldots 2018$.

$G$ and $E$ are unique up to multiplication by positive constants that calibrate them in singles, twenties, fifties, hundreds, thousands, millions, billions, or trillions of current US\$ for $G$ and hours, days, weeks, months, or years for $E$.

Definition 2. If a fractional polynomial regression of $E$ on $G$ over $t=1991 \ldots$ 2018 returns an $\mathrm{R}^{2} \geq 0.95$, then $\boldsymbol{G} F P$-causes $\boldsymbol{E}$.

The following Tobrina algorithm returns an importance-weighted fractional polynomial regression in Stata syntax (StataCorp., 2011):

fracpoly regress $E \boldsymbol{G}$ [iweight = POPmillions], adjust(G:mean) degree(2) noscaling

$\mathrm{R}^{2}=0.9794$ for this regression of $\boldsymbol{E}$ on $\boldsymbol{G}$ over $t=1991 \ldots 2018$. It is important to note that this $\mathrm{R}^{2}$ is invariant with respect to the units in which $E$ and $G$ are calibrated: i.e. hours, days, weeks, months, or years for $E$, and single, hundreds, thousands, millions, billions, or trillions of current US\$ for $G$.

The fitted $\mathrm{R}^{2}$ of 0.9794 gives strong empirical confirmation that $G F P$-causes $E$. It remains to be shown if GDP FP-causes life expectancy at birth in each of 
the G20 nations over 1991-2018. The yearly, pre-pandemic, within-nation life-expectancy increments can then be compared with subsequent decrements to assess a viral effect on national life expectancy at birth. These comparisons will expose cross-national inequalities in the viral effect due to varying wealth of nations.

\section{Dollar and Yearly Indicators in Data Science}

The theory and results in Section 3 override the basic canon of statistical inference, that there is fundamental uncertainty in all data. Neither denying nor quantifying uncertainty, we simply ignore it. This approach to sequential populations brings compelling advantages to social data science. Probabilistic inference is replaced by parameter computation and random variables give way to real variables. This suggests further "statistical thinking and new foundational frameworks" that help sort out "the many philosophical issues data science presents ..." (Davidian, 2013). This call has been echoed by the American National Science Foundation, who has "released a revised version of the solicitation 'Critical Techniques and Technologies for Advancing Foundations and Applications of Big Data Science ...”' (Vogelius et al., 2015). In view of trade-war, COVID-19, and environmental shocks to all economies, focusing data science on GDP's transformations to important global and national indexes is now compelling.

In "Advancing Foundations and Applications of Big Data Science" Pfeffermann observes that "The use of big data does not require a sampling frame, questionnaires, interviews, and all the other ingredients underlying survey samples [...] this should be the ultimate target of every country-having sufficiently accurate administrative records so that no population censuses will be needed" (Pfeffermann, 2015: pp. 433, 455).

Horrigan also views Big Data as non-sampled data "from electronic sources whose primary purpose is something other than statistical inference. [...] this type of Big Data typically comprises the universe and, by definition, can represent (nearly) the entire population [...]". (Horrigan, 2013: pp. 25-26) As examples of non-sampled universe files Horrigan mentions daily price indexes, point-of-sale retail databases, universe data on hospitals, and corporate data. $\mathrm{Si}$ milarly, the theory in Section 4 here exploits the electronic files of the World Bank, from which $\mathrm{R}^{2}=0.9794$ is returned when life expectancy at birth in years is regressed on GDP in trillions of US\$. These two variables, along with those mentioned by Horrigan, are measured on ratio scales, which exceed interval scales in the hierarchy of scientific measurement (Stevens, 1946; Torgerson, 1958; Suppes \& Zinnes, 1963).

For almost half a century interval scales have been beset by skepticism about their incremental benefits over and above ratio scales already in use (Shapiro, 1972). The problems associated with interval scaling, i.e. sampling and interrogating individuals, probabilistic inference, and significance testing, are absent with ratio-scaled dollar and yearly indicators. 
The fractional polynomial regression run in Section 4 evades the host of long-standing, and now acute, issues daunting micro-data collection and analysis. First, sampled micro data are beset by the unresolved competition between randomization-based and model-based regression (Chaudhuri \& Stenger, 2005; Opsomer, 2009). Second, both types of regression face problems of measurement error (Bound, Brown, \& Mathiowetz, 2001), sampling error (Thompson, 1997, Lohr, 2010; Brick \& Montaquila, 2009), unit nonresponse (Frankovic, Panagopoulos, \& Shapiro, 2009), missing data (Little \& Rubin, 2002), and variance estimation (Demnati \& Rao, 2004; Prášková \& Sen, 2009). Unit nonresponse alone threatens the entire survey industry due to public unwillingness to answer mail, telephone, internet, or face-to-face questions. The host of problems associated with survey measurement and process quality were discussed and illustrated over two decades ago (Lyberg et al., 1997). Today Bradburn laments that "[...] the challenges confronting the survey researcher are dominated by the difficulty in locating sample persons and getting them to respond at all." (Bradburn, 2016: p. 94).

\section{Conclusion}

IMF's Chief Economist Gita Gopinath, warned of a drop in global economic outlook in 2020 (CNBC, 24 June, 2020). On this same day she predicted that worldwide GDP will shrink 4.9\% in 2020 (Aljazeera, 24 June, 2020). In the second quarter US and German GDP then fell 10\%, the largest quarterly drop for these two nations since WWII. At an annualized rate, the American Economy contracted by one third of its value in 2020 due to COVID19 (CNBC and Aljazeera, 30 July, 2020).

This American GDP contraction has reversed in 2021 due to the liberal monetary policy of President Biden, Treasury Secretary Yellen, and Federal Reserve Chairmen Powell (CNBC, May, 2021). American GDP, as a long-term percentage of world GDP, is $29.09 \%$

(https://ycharts.com/indicators/us gdp as a percentage of world gdp). This percentage supports $\mathrm{R}^{2}=0.9794$ in Section 4 showing that world GDP drives world life expectancy-a natural outcome of comfort, security, and well-being. This finding is brought by only two data definitions and one Stata regression (StataCorp, 2011). It remains to be seen if the World Bank or IMF can also show that national GDP FP-causes national life expectancy at birth in every nation. Yearly, pre-pandemic, within-nation life-expectancy increments can then be compared with subsequent decrements to assess an endogenous viral effect on world life expectancy at birth. These comparisons will expose cross-national inequalities in this viral effect due to the varying wealth of nations.

\section{Acknowledgements}

This chapter is dedicated to the memory of the author's best critic, Maria Cohn Bechtel. The author thanks Dr. Bethany Bechtel for the book The Great Invention: The Story of GDP and the Making and Unmaking of the Modern World 
(Masood, 2016). We have also benefited from Dr. Bechtel's insistence on monitoring a population's economic indicators over time, coupled with a gradual approach to loosening entrenched economic approaches to data analysis. This paper generalizes previous work reported in G. Bechtel and T. Bechtel (2020a, 2020b). The author thanks the reviewers of both of these open access articles for their stringent reviews, which have strengthened this article's content and clarity. Tobrina Jolly and Editor Alice Yao have helped bring the open-access message here to the world's public.

\section{Conflicts of Interest}

The author declares no conflicts of interest.

\section{References}

Bechtel, G., \& Bechtel, T. (2020a). American GDP Alone Predicts Human Development. Advances in Social Sciences Research Journal, 7, 273-282. https://doi.org/10.14738/assrj.79.9012

Bechtel, G., \& Bechtel, T. (2020b). GDP and Human Development. Open Journal of Social Sciences, 8, 333-343. https://doi.org/10.4236/jss.2020.811030

Bound, J., Brown, C., \& Mathiowetz, N. (2001). Measurement Error in Survey Data. In J. J. Heckman, \& E. Leamer (Eds.), Handbook of Econometrics (Volume 5, pp. 3705-3843). Amsterdam: Elsevier Science. https://doi.org/10.1016/S1573-4412(01)05012-7

Bradburn, N. (2016). Surveys as Social Interactions. Journal of Survey Statistics and Methodology, 4, 94-109. https://doi.org/10.1093/jssam/smv037

Brick, J., \& Montaquila, J. M. (2009). Nonresponse and Weighting. In D. Pfeffermann, \& C. R. Rao (Eds.), Handbook of Statistics (Sample Surveys: Design, Methods and Applications) (Volume 29A, pp. 163-185). Amsterdam: Elsevier. https://doi.org/10.1016/S0169-7161(08)00008-4

Chaudhuri, A., \& Stenger, H. (2005). Survey Sampling: Theory and Methods (2nd ed.). Boca Raton, FL: CRC Press. https://doi.org/10.1201/9781420028638

Davidian, M. (2013). Aren't We Data Science? Amstat News, July, 3-5.

Demnati, A., \& Rao, J. N. K. (2004). Linearization Variance Estimators for Survey Data. Survey Methodology, 30, 17-26.

Frankovic, K. A., Panagopoulos, C., \& Shapiro, R. Y. (2009). Opinion and Election Polls. In D. Pfeffermann, \& C. R. Rao (Eds.), Handbook of Statistics (Sample Surveys: Design, Methods and Applications) (Volume 29A, pp. 567-595). Amsterdam: Elsevier. https://doi.org/10.1016/S0169-7161(08)00022-9

Granger, C. W. J. (2001). Essays in Econometrics: The Collected Papers of Clive W.J. Granger. Cambridge: Cambridge University Press. https://doi.org/10.1017/CBO9780511753978

Horrigan, M. W. (2013). Big Data: A Perspective from the BLS. Amstat News, January, 25-27.

Keynes, J. M. (1940). How to Pay for the War. London: Macmillan.

Little, R. J. A., \& Rubin, D. B. (2002). Statistical Analysis with Missing Data. New York: Wiley and Sons. https://doi.org/10.1002/9781119013563

Lohr, S. L. (2010). Sampling: Design and Analysis (2nd ed.). Boston, MA: Brooks/Cole. 
Lyberg, L., Biemer, P., Collins, M., de Leeuw, E., Dippo, C., Schwarz, N., \& Trewin, D. (1997). Survey Measurement and Process Quality. New York: Wiley and Sons. https://doi.org/10.1002/9781118490013

Masood, E. (2016). The Great Invention: The Story of GDP and the Making and Unmaking of the Modern World. New York: Pegasus Books Ltd.

Opsomer, J. D. (2009). Introduction to Part 4: Alternative Approaches to Inference from Survey Data. In D. Pfeffermann, \& C. R. Rao (Eds.), Handbook of Statistics (Sample Surveys: Inference and Analysis) (Volume 29B, pp. 3-9). Amsterdam: Elsevier. https://doi.org/10.1016/S0169-7161(09)70040-9

Pfeffermann, D. (2015). Methodological Issues and Challenges in the Production of Official Statistics, 24th Annual Morris Hansen Lecture. Journal of Survey Statistics and Methodology, 3, 425-467. https://doi.org/10.1093/jssam/smv035

Prášková, Z., \& Sen, P. K. (2009). Asymptotics in Finite Population Sampling. In D. Pfeffermann, \& C. R. Rao (Eds.), Handbook of Statistics (Sample Surveys: Inference and Analysis) (Volume 29B, pp. 489-522). Amsterdam: Elsevier. https://doi.org/10.1016/S0169-7161(09)00240-5

Royston, P., \& Altman, D. J. (1994). Regression Using Fractional Polynomials of Continuous Covariates: Parsimonious Parametric Modeling (with Discussion). Applied Statistics, 43, 429-467. https://doi.org/10.2307/2986270

Shapiro, H. (1972). The Index of Consumer Sentiment and Economic Forecasting: A Reappraisal. In B. Strumpel, J. N. Morgan, \& E. Zahn (Eds.), Human Behavior in Economic Affairs (p. 373). San Francisco, CA: Jossey-Bass.

StataCorp. (2011). Stata Statistical Software, Release 12. College Station, TX: StataCorp LP.

Stevens, S. S. (1946). On the Theory of Scales of Measurement. Science, 103, 677-680. https://doi.org/10.1126/science.103.2684.677

Suppes, P., \& Zinnes, J. L. (1963). Basic Measurement Theory. In R. R. Bush, R. D. Luce, \& E. Galanter (Eds.), Handbook of Mathematical Psychology, Volume I (pp. 1-76). New York: John Wiley \& Sons.

Thompson, M. E. (1997). Theory of Sample Surveys. London: Chapman Hall. https://doi.org/10.1007/978-1-4899-2885-6

Torgerson, W. S. (1958). Theory and Methods of Scaling. New York: John Wiley \& Sons.

Vogelius, M., Kannan, N., \& Huo, X. (2015). NSF Big Data Funding Opportunity for the Statistics Community. Amstat News, April, 6. 